DOI 10.37882/2223-2982.2021.06.20

\title{
СОЦИАЛЬНАЯ МОБИЛЬНОСТЬ КУПЕЧЕСТВА В КОНЦЕ XVIII - НАЧАЛЕ XX В. (ПО МАТЕРИАЛАМ ВЛАДИМИРСКОЙ ГУБЕРНИИ)
}

\section{SOCIAL MOBILITY OF MERCHANTS IN THE LATE 18TH - EARLY 20TH CENTURIES (BASED ON MATERIALS FROM THE VLADIMIR PROVINCE)}

\section{E. Ilina \\ T. Golubkina}

Summary: The aim of the study is to identify the ways of social vertical mobility of the merchants of the Vladimir province in the XIX - early XX centuries. on the basis of archival materials. The study of this topic will contribute to the understanding of the diverse social transformations in imperial Russia.

Keywords: merchants, social mobility, marriage, social lifts, estate.
A ктуальность темы исследования обусловлена изучением процессов, происходивших в сословном строе России в XIX - начале XX в. Термин «социальная мобильность» в 1927 г. ввел социолог П.А. Сорокин. Под ним понимается любой переход индивида или социальной группы из одной социальной позиции в другую. Существует два основных типа социальной мобильности: горизонтальная и вертикальная. В зависимости от направления перемещения существует два вида вертикальной мобильности: восходящая и нисходящая [26, с. 302]. В статье рассматривается лишь восходящая модель социальной мобильности, так как именно этот вид в большей степени повлиял на структурные изменения в купеческом сословии.

Для достижения этой цели были поставлены следующие задачи: выявить способы изменения социального статуса в среде купечества XIX - начала XX в., привести примеры социальной мобильности купечества во Владимирской губернии, уточнить, почему не все купцы достигали желаемого результата и оставались в своем сословии. В ходе изучения социальной мобильности в среде купечества были использованы следующие методы исследования: историзма, научности, объективности. Теоретической базой исследования является труд А.И. Аксенова [1] по генеалогии московского купечества, а также труды по формированию буржуазии А.Н. Боханова [5], социальной истории Б.Н. Миронова, П.А. Сорокина $[17,24]$, экономической истории В.Я. Чернышева [25], статьи И.Е. Викулова, Т.В. Кукиной $[6,16]$, мемуары
Ильина Елизавета Борисовна аспирант, Московский государственный областной университет

Elizaveta-ilina-1995@mail.ru

Голубкина Татьяна Михайловна

К.и.н., доцент, Владимирский государственный университет им. А.Г. и Н.Г. Столетовых golubkina@vtsnet.ru

Аннотация: Целью исследования является выявление путей социальной вертикальной мобильности купечества Владимирской губернии в XIX - начале XX в. на основе архивных материалов. Изучение этой темы будет способствовать пониманию многообразных социальных трансформаций в императорской России.

Ключевые слова: купечество, социальная мобильность, брак, социальные лифты, сословие.

А.П. Боткиной, В.В. Саблиной $[4,23]$.

Большинство историков сходятся во мнении, что к 70-м - 80-м годам XVIII в. в России сложилось сословное общество. В дореволюционной историографии по этой проблеме имелось несколько точек зрения, но их можно свести к двум концепциям. Согласно первой (С.М. Соловьев, В.О. Ключевский, и др.), сословная иерархия сформировалась к XVIII в. естественным путем, в ходе политического, социального и экономического развития страны. Ход событий требовал развития сословий, поэтому государство всемерно этому способствовало. Жалованные грамоты дворянству и городам 1785 г. стали юридическим итогом этой тенденции. Реформы 1860-1870-х гг. имели воздействие на все сферы жизни в России. Поэтому сословный строй государства начал разрушаться, и постепенно стали формироваться классы [15, с. 305-306, 462-466]. Вторая концепция (П.Н. Милюков) отличалась тем, что считала сословный строй в России хрупкой, недолговечной и искусственной структурой, созданной в результате попыток государства привить к российскому «древу» чужие западноевропейские начала $[17$, с. 77$]$.

Тем не менее, в первой половине XIX в. купечество было стабильно и имело юридические права. Оно являлось подвижным сословием, поскольку его представителям было необходимо ежегодно доказывать свою состоятельность. Поэтому выявление источников по социальной мобильности купечества достаточно про- 
блематично в виду высокой подвижности сословия. Наиболее интересна для исследования вертикальная мобильность, то есть перемещение индивида из одного социального пласта в другой. Общественное устройство в XVIII-XIX вв. позволяло купечеству изменять свой социальный статус. Одним из способов являлся брак, посредством которого можно было изменить не только свой сословный статус, но и поправить финансовое положение. Для купечества XVIII в. были характерны внутрисословные браки - жен и мужей искали в своей среде. Например, по 5-й ревизии купцов, мещан, дворовых людей города Александрова за 1795 г., среди посадскими, т.е. между купеческими семьями таких браков - 23, с крестьянами - 10 (чаще искали «вторую половину» из соседних деревень), чуть реже браки с мещанами - 7, самыми редкими были браки с иногородними - 5 [8].

К началу XIX В. положение купечества стало меняться, поэтому браки внутри своего круга хотя и имели большое значение, но постепенно их количество уменьшалось. Богатейшее купечество, связанное с государственными поставками, дворянами, которые имели большое количество крестьян и мастеровых, желало стать частью «барского» сообщества. Купцы этой категории достаточно часто добивались дворянских титулов, становились родственниками представителей первого сословия. Одним из способов изменить сословное положение своего потомства, а точнее, его женской части, был брак купеческой дочери с дворянином. Правда, такие браки не были многочисленными, учитывая замкнутость сословия и пренебрежительное отношение дворян к купечеству. Для дворянства межсословные браки были более характерны (60\% браков заключались с представителями духовенства и купечества) [15, с. 140]. С помощью браков по расчету обедневшие дворянские семьи могли поправить свои дела, а купцы получали возможность породниться с благородным сословием [25, с. 157].

Браки заключались между наиболее богатыми купцами города и дворянами невысоких чинов: офицерами, чиновниками. Таким примером могут служить браки дочерей одного из самых уважаемых купцов города Мурома первой четверти XIX в. Егора Зворыкина. Старшая дочь Александра вышла замуж за подполковника Александра Францевича Подседлевича, вторая дочь Анна за штабс-капитана Павла Александровича Толстого [25, с. 129]. Из дневника муромского купца Владимира Макаровича Емельянова следует, что в 1878 г. дочь городского головы В.М. Емельянова, Елизавета Макаровна вышла замуж за майора и учителя гимнастики в Муромском реальном училище Александра Павловича Золотарева [12]. Иногда купеческие дочери выходили замуж за потомственных дворян. Так в 1907 г. Борис Михайлович Саблин, юрист и адвокат, представитель известного дворянского рода женился на Елизавете Асафовне Барановой, дочери потомственного почетного граждани- на, купца 1-й гильдии и миллионера А.И. Баранова. Этот брак продлился 14 лет и завершился разводом в 1921 г., но Е.А. Баранова-Саблина повторно вышла замуж также за представителя дворянского рода Владимира Сергеевича Бартенева [23, с. 61, 62].

Что касается браков между дворянками и купцами, то они были крайне редки, так как дворянства по жене не предоставлялось. Дворянка после замужества могла сохранить свой статус, но передать его детям не могла. Тем не менее, такие браки заключались во Владимирской губернии. Они поднимали авторитет купца и его семьи, но на подобный союз могли рассчитывать самые выдающиеся представители городского общества. Например, муромский купец 1-й гильдии Николай Андрианович Мяздриков был женат на дочери муромского дворянина, титулярного советника Дмитрия Сергеевича Епишева [25, с. 129].

Одним из самых надежных способов получить дворянство была воинская служба. В Табеле о рангах даже самый низкий 14 класс давал право на потомственное дворянство. С 1845 года его получали с чина 8-го класса (майор), а с 1856 года - с 6-го чина (полковник). Купечество, как сословие, не подлежало рекрутской повинности, поэтому его представители могли поступить на службу вольноопределяющимися и иметь льготные условия для прохождения службы. Вольноопределяющиеся служили 4 года до производства в унтер-офицеры, и еще 4 года для производства в офицеры. Но в некоторых случаях эти сроки могли быть сокращены, например, для студентов университетов. Поэтому некоторые купеческие сыновья покидали сословие ради воинской службы. Благодаря военной службе стали дворянами в конце XVIII в. потомки древних суздальских купеческих родов Лихониных и Зубковых, перебравшихся в Москву еще в середине столетия [1, с. 87].

В 1779 г. сын юрьев-польского купца Ивана Петровича Карцева Федор выбыл в военное сословие [9, д. 174]. Его боевой путь не известен, но в 1812 году он уже являлся отставным штабс-капитаном, более того, принимал участие во Владимирском ополчении, будучи сотенным начальником. Его сын Платон начинал военную службу в этом же полку пятидесятником. Впоследствии он служил в егерском, драгунском и других полках. Платон Карцев вышел в отставку в 1823 г. в возрасте 28 лет в чине штабс-капитана [8, д. 342, л. 2]. У Ивана Карцева был старший брат Петр, один из самых богатых купцов города Юрьева, сколотивший капитал на питейных откупах. Он не имел своих детей, но взял на воспитание Василия Яковлевича Телегина, которому завещал свое состояние. В 1812 г. двадцатилетний Василий поступил урядником во Владимирское ополчение и после войны не вернулся в купеческое сословие, продолжив военную службу. К 1824 году он дослужился до штабс-капитана и оставил 
службу [11, д. 262, л. 1, 2].

В семье муромского купца Николая Васильевича Суздальцева в 1890 г. родился сын Владимир. В 1908 г. он окончил Муромское реальное училище, а затем Петровскую сельскохозяйственную академию в Москве, получив специальность агронома. В 1915 г. В.Н. Суздальцев как офицер ушел на фронт. В 1917 г. около полугода он воевал на Юго-Западном фронте в должности полкового оперативного адъютанта, имел звание поручика [6, c. 257]. В том же Муроме 27 июня 1896 г. в Сретенской церкви состоялось венчание дочери потомственного почетного гражданина, купца 1-й гильдии Козьмы Алексеевича Зворыкина, Надежды и Степана Фроловича Неизвестнова, сына купца 1-й гильдии и уволенного в запас армии нижнего чина Астрахани [10, д. 753, л. 52]. Военную службу выбрали и сыновья мстёрского купца Василия Панкратова. Двое из них проходили службу в армии: Иван - фельдшером в лейб-гвардии Его Величества Кирасирском полку, в 1904-1909 гг. он уже был заведующим Мстёрским военно-конским участком, а Василий писарем в лейб-гвардии Литовском полку [2, д. 325, л. 40; 12 , с. $27 ; 15$, с. 201].

Имело место и пожалование дворянства высочайшими повелениями. Таким примером может стать род промышленников и купцов Баташевых. В правление императрицы Елизаветы Петровны крупными заводчиками Андреем и Иваном Баташевыми на Владимирской земле в октябре 1759 г. на реке Гусь в районе села Веркуц был основан чугуноплавильный и железоделательный завод [3, с. 12]. Потомки тульских кузнецов Баташевы были пожалованы дворянством в 1783 г., в качестве награды за их усердную службу на благо государства и своевременное исполнение казенных заказов.

Сюда же можно отнести и возведение во дворянство вследствие награждения орденами Российской Империи. Награждение орденом 1-й степени позволяло получить личное дворянство, ордена Св. Георгия и Св. Владимира любой степени давало потомственное дворянство. Например, такой награды удостоился купец города Переславля-Залесского Алексей Алексеевич Куманин, переселившийся в 1789 г. в Москву. Богатый купец 1-й гильдии, московский городской голова прославился тем, что стал одним из инициаторов создания народного ополчения 1812 г. Он лично пожертвовал 50000 руб. на его нужды. За свои заслуги он был награжден орденом «Св. Владимира» 4-й степени, и впоследствии стал дворянином [19, с. 4].

«Жалованная грамота городам» 1785 г. создавала новую сословную группу именитых граждан, которая объединяла разные группы горожан в том числе и купцов, занимающихся исключительно оптовой торговлей, банкиров, а также лиц, кто «проходя по порядку службу городскую и получив уже название степенных, вторично по выборе отправили службу мещанского заседателя совестнаго суда или губернскаго магистрата, или бургомистра, или городскаго главы с похвалою». 137 статья городового положения постановляла: «Имянитых граждан внучатам, буде дед, отец и они имянитость беспорочно сохраняли, дозволяется старшему после тридцати лет от рождения его, быв самому жизни беспорочной, просить дворянства» [21]. Такой способ получения дворянства для купечества был весьма ненадежным, учитывая, с одной стороны, нестабильность благосостояния представителей торгово-промышленных кругов и, соответственно, их социального положения, а с другой - отмену этого звания для купечества в 1807 г.

В 1836 г. в Сенат было направлен рапорт от владимирского гражданского губернатора, к которому прилагалось прошение от 1-й гильдии купца и потомственного почетного гражданина Ивана Сарачева о предоставлении дворянского достоинства. Основанием для этого он считал 137 статью Городового положения и подтверждение этой статьи в примечаниях к 27 статье 9 тома Свода законов. В прошении говорилось, что сам он Иван Прохорович Сарачев, его дед Борис Тимофеевич и отец Прохор Борисович купцы города Покрова «по служению своему в городских службах и производимому оптовую торгу приобрели полное право на именитость» [11, д. 841, л. 2].

Согласно приложенным к прошению документам, Иван Сарачев и его предки «лавок не имели, в них не сидели, ибо торговлю производили оптовую железом при портах Одесском, Таганрогском и Астраханском и при Санкт-Петербургском порту салом. Несостоятельности не попадали, никаким взысканиям, искам, утратам и недоимкам не подвергались». Все они в разное время состояли городскими головами города Покрова, Прохор и Иван были награждены золотыми медалями «За усердие» на Владимирской ленте. Они имели также лестные характеристики от покровского магистрата и уездного суда: «вели жизнь при хорошем поведении и добронравии, как надлежит быть, честные степенные и благонадежные граждане», «вели жизнь и состояние благородно и именитость сохранили бесспорно» [11, д. 841, л. 3]. Однако рассмотрение дела было отложено, так как в Сенате находилось аналогичное дело нарвского купца Андрея Чернова. В феврале 1838 г. дело купца Сарачева было вновь принято на рассмотрение. Но сенаторы решили, что Борис Сарачев мог пользоваться званием именитого гражданина и быть внесенным в специальный раздел обывательской книги, однако по документам неясно, было ли это исполнено. То же касалось и его сына Прохора Сарачева, так как свою службу он проходил после 1807 г., когда был принят манифест об отмене звания именитых граждан для купцов. Поэтому большинство сенаторов было «против» и в просьбе купцам отказали. 
Сенатор В.И. Гегевич был против отказа, так как Сарачевы занимались оптовой торговлей и соответствовали требованиям именитости. У губернского начальства была затребована справка о внесении Сарачевых в 5-ю часть обывательской книги, куда записывали именитых граждан. Но в Покровской городской думе книга для записывания именитого купечества не заводилась, поэтому Сарачевы не были в нее вписаны [11, д. 841, л. 3]. Так как дело осложнилось, то Сенатом было принято решение передать его на рассмотрение императора Николая I, который пожаловал Сарачевым дворянство. В «Московском некрополе» 1907 г. есть сведения об Иване Сарачеве, его супруге и детях. Они похоронены на кладбище Новоспасского монастыря и записаны как почетные граждане и дворяне [18, с. 1075].

По правилам чинопроизводства в России лица, занимавшие выборные должности в купеческом управлении, пользовались некоторыми правами: старшина сословия приравнивался к чину коллежского советника (VI класс), члены купеческой управы - к надворным советникам (VII класс). Однако фактически купцы не получали дворянство за выполнение подобных функций. На государственную службу могли поступить дети коммерц-советников, купцов 1-й гильдии или купцы, получившие чин вне порядка службы [22, с. 2, 10]. Некоторые представители купечества Владимирской губернии имели высокие чины: А.И. Баранов получил звание мануфактур-советника и почетную степень инженера-технолога [26, с. 4]. Купцы могли получать чины до 1892 г., когда были утверждены «Правила о наградах», отменившие для них производство в чины $[22$, с. 2,10$]$. С этого момента купечество стало стремиться получить личное или потомственное почетное гражданство, чтобы добиться дополнительных привилегий и обеспечить себе стабильное общественное положение.

Самым распространенным способом обеспечить себе дворянство или почетное гражданство стали благотворительность, меценатство и общественная деятельность. Так, потомственное почетное гражданство получили: муромские купцы Мяздриков Андриан в 1834 г., Мяздриков Петр в 1834 г., Крашенинников Афанасий с семьей в 1838 г., Суздальцев Иван с семьей и братом Федором с семьей в 1839 г., в 1840 году муромская купеческая жена Усова Матрена с детьми, в 1841 году александров- ский купец Баранов Иван с женой Александров Асафовной и детьми, в 1842 муромский купец Усов Прокопий с семейством [20, с. 259, 273, 285, 294, 304]. Император Николай II, согласно положению Комитета о службе чинов гражданского ведомства и о наградах, «соизволил» в 1908 году пожаловать ко дню Святой Пасхи директора Владимирского губернского тюремного комитета купца 2-й гильдии Василия Гончарова за заслуги по тюремному ведомству званием потомственного почетного гражданина [7, д. 13, л. 20]. Таким образом, почетное гражданство являлось привилегированной прослойкой между непривилегированным купечеством и дворянством.

Купеческие дети могли стать личными почетными гражданами, получив высшее образование. Большое количество представителей владимирского купечества сумели достичь этой цели, например: Е.И. Баранова обучалась в Коллеж де Франс, В.Н. Суздальцев в Петровской сельскохозяйственной академии в Москве, А.М., П.В., С.М. Зубовы и Н.Н. Зворыкин - в Московском университете, Е.И. Зворыкин - в Санкт-Петербургском университете [5, с. 115; 6, с. 158; 17, с. 29-31]. Наивысшим поощрением в Российской империи являлось дарование потомственного дворянства. Но даже для столичного купечества в начале XX в. приобретение такого статуса было редкостью, так как это шло вразрез с сословнокорпоративными принципами той эпохи [5, с. 69]. В среде владимирского купечества не выявлено ни одного лица, оказавшегося в числе потомственных дворян.

Можно сделать вывод, что в рассматриваемый период социальная мобильность в купеческой среде была достаточно динамична, однако большинство коммерсантов так и не смогли достичь желаемой цели, так как подняться по сословной лестнице могли лишь самые богатые и уважаемые представители сословия. Повысить свой социальный статус могли также люди целеустремленные и готовые на риск, т.е. поступавшие на военную службу. Поэтому «дворянство интенсивно получало свежую кровь, что усиливало его интеллектуальный и, так сказать, энергетический потенциал» [17, с. 146]. Перспективы дальнейшего исследования проблемы мы видим в более детальном изучении социальной мобильности, а также выявлении факторов, которые удерживали основную массу купечества в своем сословии или заставляли покидать его, пополняя ряды интеллигенции.

\section{ЛИТЕРАТУРА}

1. Аксенов А.И. Генеалогия московского купечества XVIII в. Из истории формирования русской буржуазии Москва: Наука, 1988. 198 с.

2. Архив ЗАГС Муниципального образования Вязниковский район. Ф. 5. Оп. 7.

3. Богатов И.П. Металлургическая промышленность владимирской губернии: материалы истории металлургии Приокского округа. Владимир: Владим. губ. науч. 0-во по изучению местного края: Губ. плановая комиссия, 1929 (типо-лит. № 1 Владполиграфтреста). 1922. 49 с.

4. Боткина А.П. Павел Михайлович Третьяков в жизни и искусстве. М.: Атр-Волхонка, 2012.632 с. 
5. Боханов А.Н. Крупная буржуазия России (конец ХІХ в. - 1914 г.). Москва: Наука, 1992. 260 с.

6. Викулов И.Е. В Истории муромского рода Суздальцевых. Жизненный путь Н.В. Суздальцевой // Материалы областной краеведческой конференции «Известные и неизвестные события и имена в истории и культуре Владимирской земли» (18 апреля 2003 г.) / Владимирский фонд культуры; Владимирское общество краеведов; ГУ «Владимирская областная научная библиотека». Владимир: Атлас, 2003. 310 с.

7. Государственный Архив Владимирской Области (далее - ГАВО). Ф. 90. Оп.1.

8. ГАВО.Ф. 243.0п. 3.

9. ГАВО.Ф. 301.0п. 5 .

10. ГАВО. Ф. 590. Оп.1.

11. ГАВО. Ф. 789. Оп. 1.

12. Дневник В.М. Емельянова [Электронный ресурс] https://museum-murom.ru/scientific-work/sources-publishing/dnevnik-v.-m.-emelyanova

13. Журналы очередного и экстренных Вязниковских уездных земских собраний 1903 года. Владимир: Владимир на Клязьме, 1904. 284 с.

14. Журналы Вязниковского уездного земского собрания очередной сессии 1906 года с приложениями. Владимир на Клязьме, 1906. 275 с.

15. Ключевский В.0. История сословий в России: курс, чит. в Моск. ун-те в 1886 г. Изд. 2-е. М.: Тип. П.П. Рябушинского, 1914. 254 с.

16. Кукина Т.В. Из истории Александровского купеческого рода Зубовых // Зубовские чтения: сборник статей. Вып.1. Владимир: Издатель А. Вохмин, 2002. С. $26-32$.

17. Миронов Б.Н. Социальная история России периода империи (XVIII - начало XX в.): В 2 т. 3-е изд., испр., доп. СПб.: Дмитрий Буланин, 2003.587 с.

18. Московский некрополь. Т. 3: (Р-囚). СПб.: Тип. М.М. Стасюлевича, 1908. 1075 с.

19. Никитина Ю.Я. Заслуги перед Отечеством // Славич. 1997. 7 марта.

20. Петров А. Памятная книжка российской промышленности. СПб.: Типография Августа Семена при Императорской медико-хирургической академии, 1843. 319 c.

21. Полное собрание законов Российской империи. Т. ХХІІ. СПб.: Типография II отделения Собственной Его Императорского Величества канцелярии, 1830. № 16187.

22. Свод законов Российской Империи. СПб.: [б. и.], 1876. Т. 3. Ч. 1.

23. Саблины: Годы. События. Люди / Сост. В.В. Саблина. СПб.: Алетейя, 2007. 208 с.

24. Сорокин П.А. Человек. Цивилизация. Общество / Общ. ред., сост. и предисл. А.Ю. Согомонов. М.: Политиздат, 1992. 543 с.

25. Чернышев В.Я. Московская улица (Социоэкономическая история XVII - начало XX в.). Серия «Прогулки по Мурому. Книга первая». 2-е изд. Муром: 000 «Новые технологии», 2005. 248 с.

26. Шереметьевская А.Н. Речи, произнесенные на торжественном заседании в память Е.И. Мамонтовой (25 марта 1911 г.). М.: типо-лит. М.А. Мальцева, 1911. 14 c.

() Ильина Елизавета Борисовна (Elizaveta-ilina-1995@mail.ru), Голубкина Татьяна Михайловна (golubkina@vtsnet.ru) Журнал «Современная наука: актуальные проблемы теории и практики» 